Proc. Estonian Acad. Sci. Geol., 1997, 46, 3, 127-145

\title{
GEOCHEMISTRY OF LLANDOVERY BLACK SHALES IN THE AIZPUTE-41 CORE, WEST LATVIA
}

\author{
Enli KIIPLI
}

Institute of Geology, Estonia Blvd 7, EE-0001 Tallinn, Estonia

Received 13 May 1997, accepted 9 June 1997

Abstract. The Dobele Formation (Aeronian) of the Aizpute core is represented by a black shale, $7.2 \mathrm{~m}$ thick, characterized by increased contents of trace metals. $\mathrm{Cr}, \mathrm{V}$, and Ni show constantly high average values in the vertical profile. The average ratio of $\mathrm{Cr} / \mathrm{V} / \mathrm{Ni}$ contents $1: 10: 1.9$ in excess of terrigenous contribution in the central and upper parts of the sequence approximates the corresponding interelement ratios in modern seawater. Thus these elements may have precipitated directly from seawater according to thermodynamic rules, assuming the general constancy of the seawater composition through geologic time. The bottom water in the Aizpute area was sulphatereducing below a thin denitrifying zone. $\mathrm{Pb}$, As and in some cases $\mathrm{Zn}, \mathrm{Ni}$, and $\mathrm{Mo}$, associating with pyrite, tend to concentrate on certain levels. The mechanism of incorporation of metals into sediment from seawater is diverse.

The $\mathrm{SiO}_{2} / \mathrm{Al}_{2} \mathrm{O}_{3}$ ratio is interpreted as an index of transgressions and regressions. Positive correlation between the $\mathrm{CaO}$ content and $\mathrm{SiO}_{2} / \mathrm{Al}_{2} \mathrm{O}_{3}$ ratio in black shales and an increase in both values upwards from a 0.7 -m-thick limestone interbed reveals a slight increase in carbonate sedimentation when the shallower nearshore zone shifts towards Aizpute. This regularity is not observed in the 0.7 -m-thick limestone interbed: carbonate precipitation takes place in an anoxic environment without any considerable indicators of sea-level changes and of closeness to the nearshore region. Anoxia of the basin develops independent of transgressions and regressions, as deduced from the comparison of the $\mathrm{SiO}_{2} / \mathrm{Al}_{2} \mathrm{O}_{3}$ ratio in organic-rich and -poor shales.

Key words: black shale, Aeronian, West Latvia, geochemistry, palaeobasin.

\section{INTRODUCTION}

The present investigation concentrates on problems of geochemistry of Silurian black shales in the Aizpute-41 core, West Latvia (Fig. 1). The Aizpute core, now stored at Särghaua, was given over to Estonian Institute of Geology by the Latvian Geological Survey for comparative study of the palaeobasin. 


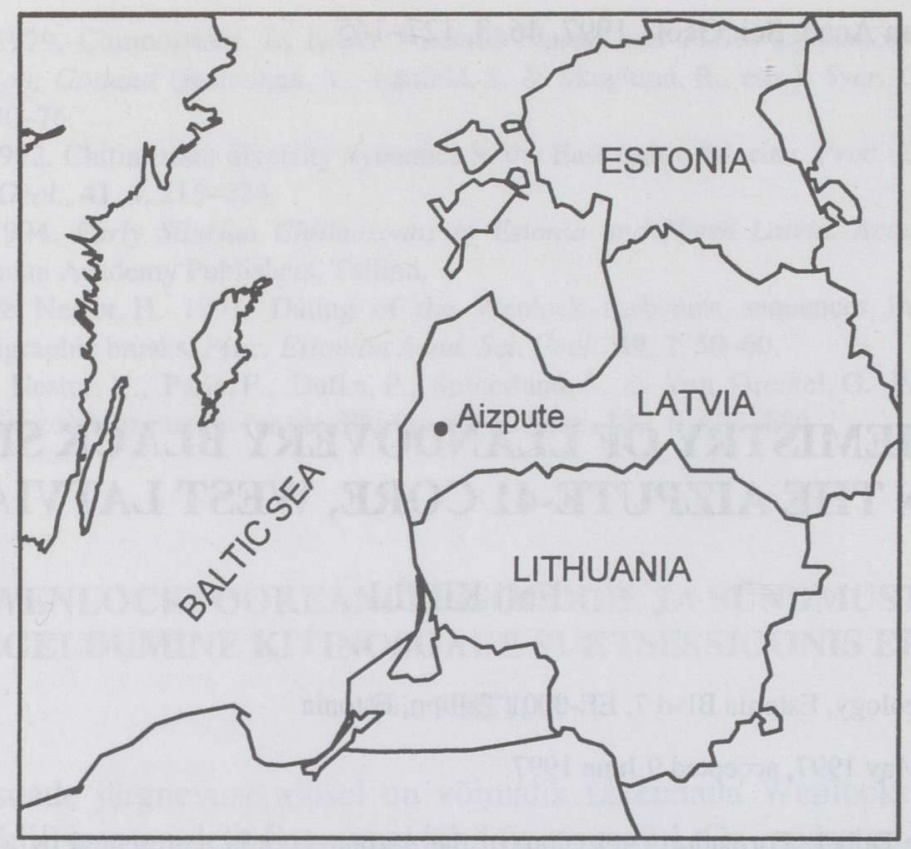

Fig. 1. Location of Aizpute borehole.

The aim of this paper was to discuss the chemistry of the basin based on the contents of metals and organic matter in black shales, mechanism of incorporation of elements into the sediment, and behaviour of terrigenous and carbonate components as reflectors of the sedimentation processes.

The name "black shales" (or "graptolitic shales") comes from the occurrence of graptolites and greyish-black or brownish-black colour of the rock caused by organic matter and fine-dispersed pyrite admixture. Black shales are characterized by an increased content of metals, exceeding the clarke.

Silurian black graptolitic shales occur in Estonia only as rare thin layers in the Aeronian (Raikküla and Adavere stages). They are widespread in West Latvia through Lithuania and Poland up to Thyringia in Germany. Facially the Silurian black shales are characterized as deep-water sediments. They were formed in the depression of the shelf plateau connected with the Central European ocean (Nestor \& Einasto, 1982). Evidently the shelf bottom water was anoxic in the Aeronian. The investigated interval of black shales belongs to the Dobele Formation, Aeronian (Table).

The presence of black shales in the shelf is associated by Berry et al. (1989) with the global sea-level rise. The lithology of the Raikküla Stage (Aeronian) in the shallow-water facies section of West and Central Estonia, on the contrary, hints at a regression (Kaljo \& Jürgenson, 1977). Bassett et al. (1989) explain the contradiction as an effect of differential fluctuations caused by broad regional 
tectonism or warping following continental collision of Baltica with Laurentia. Some aspects of the relations between the anoxic environment and eustasy will be discussed below.

Table

Stratigraphic scheme of the Early Silurian of the East Baltic

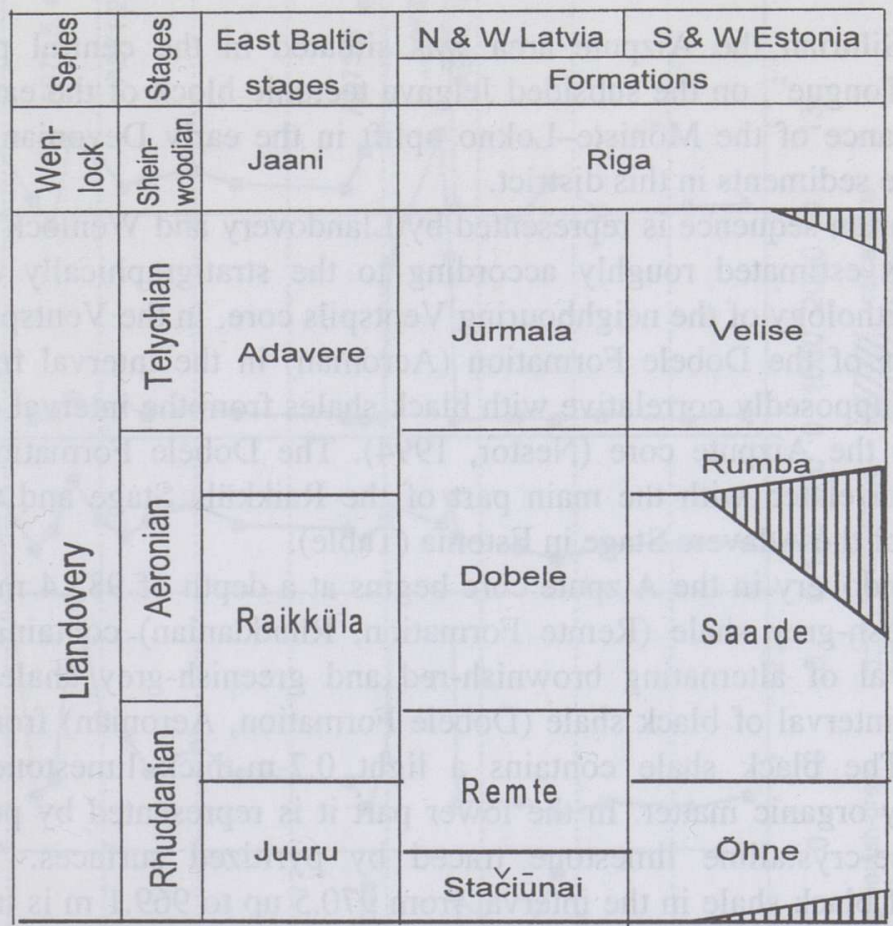

In recent basins, abundant accumulation of organic matter has taken place in limited areas with weak advection and anoxic conditions, such as the Black Sea, the Baltic Sea, the Cariaco Trench, depressions in the Californian shelf and some fjords (Aisatullin \& Skopintsev, 1979). The anoxic conditions and weak water advection are mostly caused by sills separating the basin from the ocean. In an anoxic basin the water may be sulphate-reducing for some tens to some hundreds, in the Black Sea even up to two thousand metres from the bottom. An anoxic environment occurs in deeper parts of the present Baltic Sea. The corresponding sediments and the anoxic environment have been studied by Manheim (1961), Brügmann (1988), Salonen et al. (1995), Lepland \& Stevens (1996), Brügmann et al. (1997) and others. In the Gotland Deep, $230 \mathrm{~m}$ in depth, the anoxic zone begins below $100 \mathrm{~m}$; at a depth of $200 \mathrm{~m} \mathrm{H}_{2} \mathrm{~S}$ is recorded. The electron activity (Eh) decreases to about zero in the water column. The proton activity $(\mathrm{pH})$ is higher than 7.0 in the water column and decreases to 6.8 in the sediment (Manheim, 1961). 
Black shale is an initial source of organic matter for oil, of hydrothermal solutions enriched with metals, and of ores of several rare elements. Therefore the black shale is economically important.

\section{BRIEF CHARACTERIZATION OF THE AIZPUTE CORE}

In the Silurian the Aizpute area was situated in the central part of the "Livonian Tongue", on the subsided Jelgava tectonic block of the earth's crust. The appearance of the Mõniste-Lokno uplift in the early Devonian caused an uprise of the sediments in this district.

The Silurian sequence is represented by Llandovery and Wenlock rocks. The timescale is estimated roughly according to the stratigraphically determined analogous lithology of the neighbouring Ventspils core. In the Ventspils core the black shales of the Dobele Formation (Aeronian) in the interval from 865 to $850 \mathrm{~m}$ are supposedly correlative with black shales from the interval of 976.3 to $969.1 \mathrm{~m}$ in the Aizpute core (Nestor, 1994). The Dobele Formation in West Latvia is correlated with the main part of the Raikküla Stage and the Rumba Formation of the Adavere Stage in Estonia (Table).

The Llandovery in the Aizpute core begins at a depth of $983.4 \mathrm{~m}$ with 7-mthick greenish-grey shale (Remte Formation, Rhuddanian) containing a 1-mthick interval of alternating brownish-red and greenish-grey shale. Upwards follows an interval of black shale (Dobele Formation, Aeronian) from 976.3 to $969.1 \mathrm{~m}$. The black shale contains a light 0.7 -m-thick limestone interbed, darkened by organic matter. In the lower part it is represented by pure $11-\mathrm{cm}-$ thick coarse-crystalline limestone traced by pyritized surfaces. The upper boundary of black shale in the interval from 970.5 up to $969.1 \mathrm{~m}$ is transitional: black shales alternate with 20 - $\mathrm{cm}$ grey shale interlayers. The following interval (Jūrmala Formation, Telychian) of greenish-grey, brownish-red, and grey shales is $19 \mathrm{~m}$ thick (from 969.1 up to $950 \mathrm{~m}$ ). Upwards, in the Wenlock, the sediments turn more calcareous. There occur thin-laminated bituminous and greenish-grey clays, and grey unlaminated clays. The thickness of the Wenlock in the Aizpute core is $40 \mathrm{~m}$.

\section{SAMPLING AND ANALYSE METHODS}

From the black shale interval of $977.8-969.15 \mathrm{~m} 23$ samples were collected for this study (Fig. 2). Fifteen samples come from black shales, three from the 0.7-m-thick limestone layer (A974.05, A974.6, and A974.7), two from black calcareous clay (A969.8 and A970.7), one from a dark-grey interlayer (A977.8), and two from light greenish-grey interlayers (A977.2 and A970.5). For the analysis the X-ray fluorescence method was applied, using pressed pellets of 


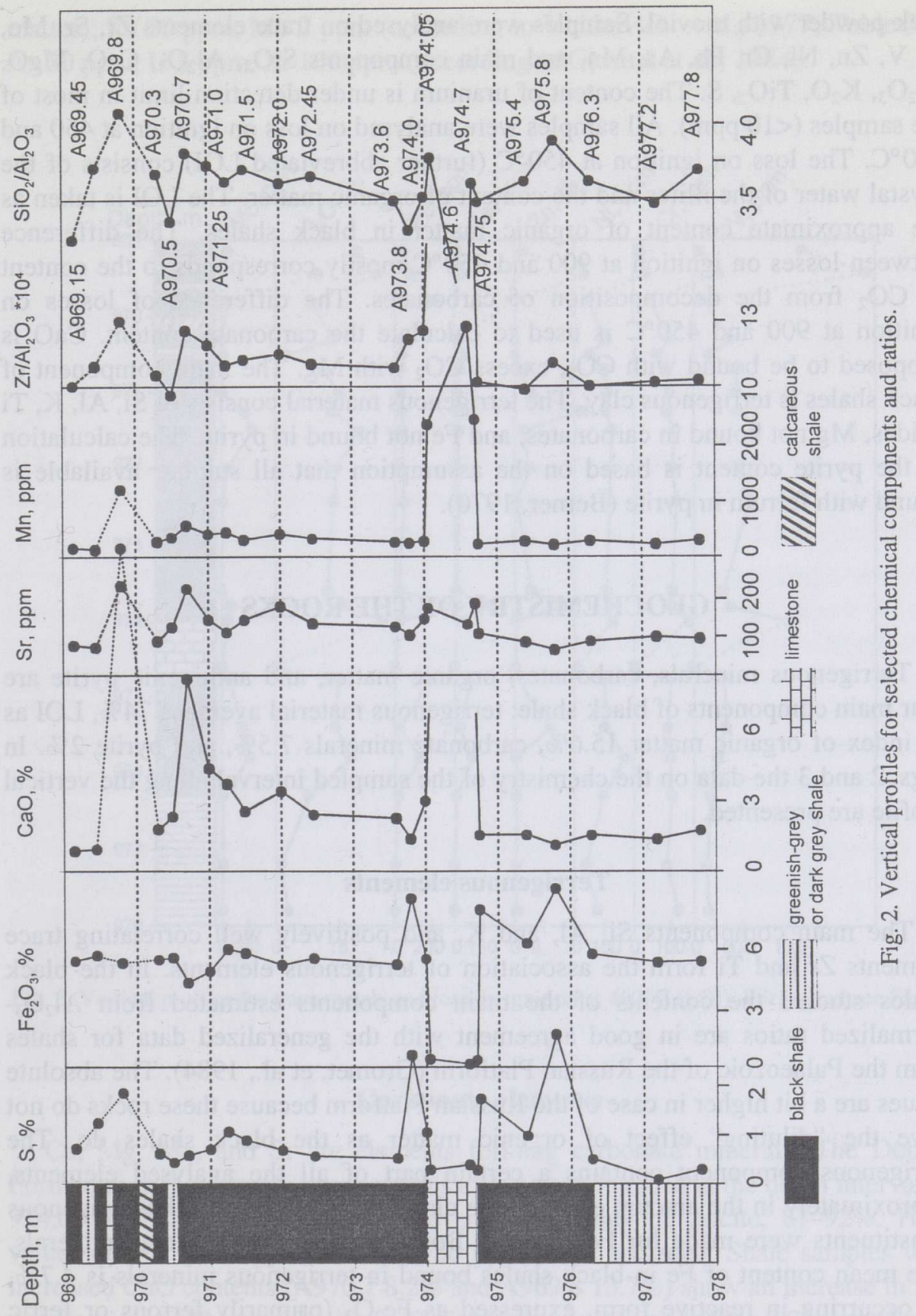


rock powder with moviol. Samples were analysed on trace elements $\mathrm{Zr}, \mathrm{Sr}$, Mo, $\mathrm{U}, \mathrm{V}, \mathrm{Zn}, \mathrm{Ni}, \mathrm{Cr}, \mathrm{Pb}, \mathrm{As}, \mathrm{Mn}$, and main components $\mathrm{SiO}_{2}, \mathrm{Al}_{2} \mathrm{O}_{3}, \mathrm{CaO}, \mathrm{MgO}$, $\mathrm{Fe}_{2} \mathrm{O}_{3}, \mathrm{~K}_{2} \mathrm{O}, \mathrm{TiO}_{2}$, S. The content of uranium is under detection limit in most of the samples $(<10 \mathrm{ppm})$. All samples were analysed on loss on ignition at 450 and $900^{\circ} \mathrm{C}$. The loss on ignition at $450^{\circ} \mathrm{C}$ (further abbreviated LOI) consists of the crystal water of the illites and the content of organic matter. The LOI is taken as the approximate content of organic matter in black shales. The difference between losses on ignition at 900 and $450^{\circ} \mathrm{C}$ mostly corresponds to the content of $\mathrm{CO}_{2}$ from the decomposition of carbonates. The difference of losses on ignition at 900 and $450^{\circ} \mathrm{C}$ is used to calculate the carbonate content. $\mathrm{CaO}$ is supposed to be bound with $\mathrm{CO}_{2}$, excess $\mathrm{CO}_{2}$ with $\mathrm{Mg}$. The main component of black shales is terrigenous clay. The terrigenous material consists of $\mathrm{Si}, \mathrm{Al}, \mathrm{K}, \mathrm{Ti}$ oxides, $\mathrm{Mg}$ not bound in carbonates, and Fe not bound in pyrite. The calculation of the pyrite content is based on the assumption that all sulphur available is bound with ferrum in pyrite (Berner, 1970).

\section{GEOCHEMISTRY OF THE ROCKS}

Terrigenous minerals, carbonates, organic matter, and authigenic pyrite are four main components of black shale: terrigenous material averages $74 \%$, LOI as an index of organic matter $15.6 \%$, carbonate minerals $7.5 \%$, and pyrite $2 \%$. In Figs. 2 and 3 the data on the chemistry of the sampled interval along the vertical profile are presented.

\section{Terrigenous elements}

The main components $\mathrm{Si}, \mathrm{Al}$, and $\mathrm{K}$, and positively well correlating trace elements $\mathrm{Zr}$ and $\mathrm{Ti}$ form the association of terrigenous elements. In the black shales studied the contents of the main components estimated from $\mathrm{Al}_{2} \mathrm{O}_{3}$ normalized ratios are in good agreement with the generalized data for shales from the Palaeozoic of the Russian Platform (Gromet, et al., 1984). The absolute values are a bit higher in case of the Russian Platform because these rocks do not have the "diluting" effect of organic matter as the black shales do. The terrigenous component contains a certain part of all the analysed elements, approximately in the amount equal to the clarke. Calculations of the terrigenous constituents were made for $\mathrm{Fe}$ and $\mathrm{Mg}$. Both elements occur in clay minerals. The mean content of $\mathrm{Fe}$ in black shales bound in terrigenous minerals is $4.7 \%$, $\mathrm{Fe}$ occurring in reactive form, expressed as $\mathrm{Fe}_{2} \mathrm{O}_{3}$ (primarily ferrous or ferric ions, oxides, and hydroxides), accounts for $1.5 \%$. In $100 \%$ terrigenous fraction the calculated $\mathrm{Fe}_{2} \mathrm{O}_{3}$ content is $5.5 \%$. The content of $\mathrm{MgO}$ bound with terrigenous minerals is $1.5 \%$. In the Aizpute core the mean contents of microelements bound in terrigenous material are as follows: $\mathrm{Ni} 40 \mathrm{ppm}, \mathrm{Cr} 77$ ppm, V 140 ppm, Zn 60 ppm (the lowest contents in the shale without organic 
matter); Pb 20 ppm, Mo 2 ppm (according to Voitkevich et al., 1977; Table 30); As 20 ppm, U 3 ppm, Zr 160 ppm (according to Gromet at al., 1984).

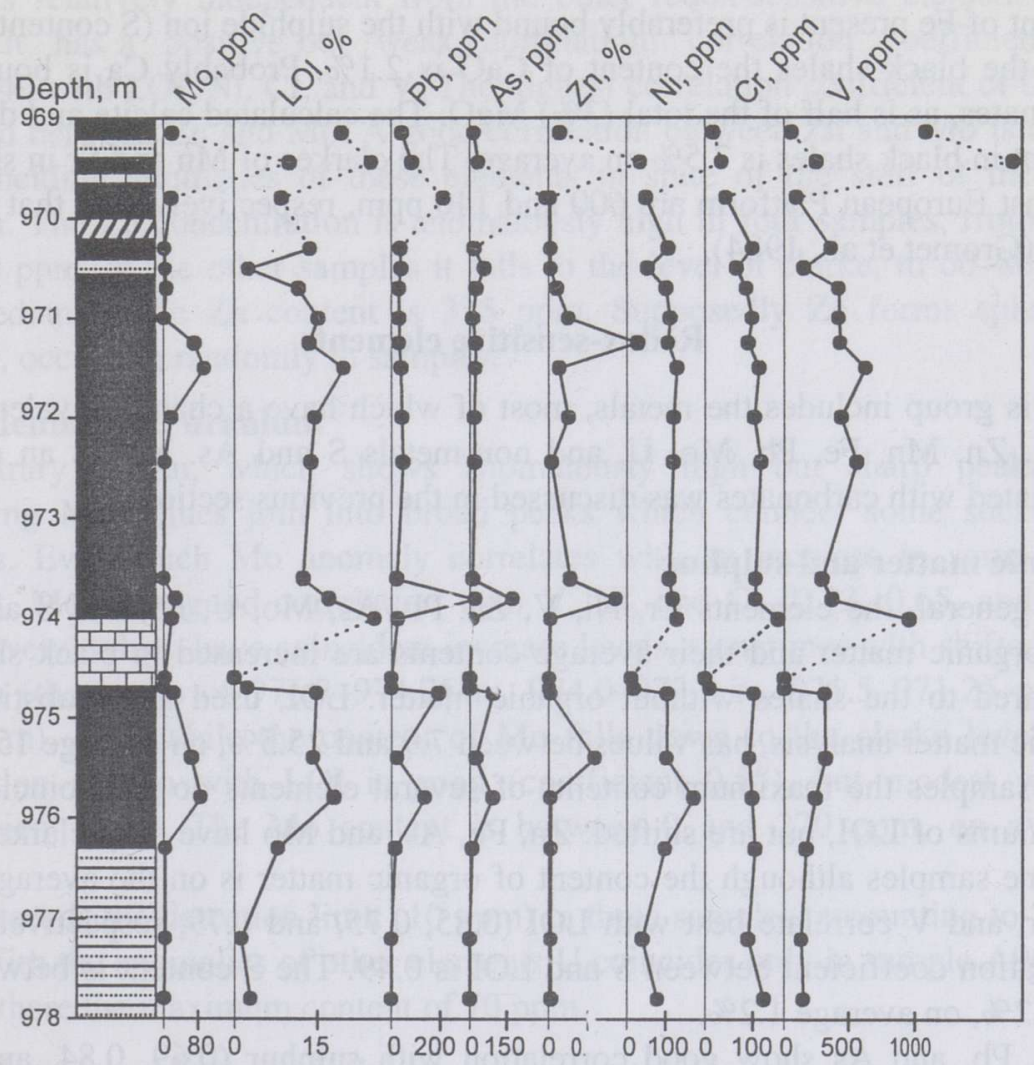

Fig. 3. Vertical profiles for trace metals and loss on ignition at $450^{\circ} \mathrm{C}$ (LOI). For legend see Fig. 2.

\section{Carbonate elements}

$\mathrm{Ca}, \mathrm{Mg}, \mathrm{Mn}$, and $\mathrm{Sr}$ are elements forming carbonate minerals. The Dobele Formation in the Aizpute core contains a limestone interbed at the depth interval of 974.05 to $974.75 \mathrm{~m}$. This limestone consists mainly of calcite, $81-92 \%$. High values of $\mathrm{Mn}(4200 \mathrm{ppm})$ and $\mathrm{Sr}(180 \mathrm{ppm})$ were recorded. Shale samples with increased $\mathrm{CaO}$ contents (A970.7 8.2\% and A969.8 13.7\%) show an increase in $\mathrm{Mn}$ and $\mathrm{Sr}$ as well. The correlation coefficient between $\mathrm{Mn}$ and $\mathrm{Ca}$ is 0.98 , correlation of $\mathrm{Sr}$ with $\mathrm{Ca}$ is weaker (coefficient 0.39 ). The correlation of $\mathrm{Mn}$ and $\mathrm{Sr}$ with the terrigenous component is negative. High values of $\mathrm{Mn}$ in limestone, supposedly in the crystal structure of calcite, indicate the presence of the $\mathrm{Mn}^{2+}$ ion in the water of the sedimentary basin or in the diagenetic environment. 
$\mathrm{Fe}$ is negatively correlated with $\mathrm{Ca}$ (correlation coefficient -0.84$)$. The $\mathrm{Fe}$ content $(0.3 \%)$ in the limestone interlayer is much lower than in the adjacent shale, and so there is no incorporation of $\mathrm{Fe}$ into the calcite crystal lattice. This shows the absence of a free $\mathrm{Fe}^{2+}$ ion in the sedimentary environment. The small amount of Fe present is preferably bound with the sulphide ion (S content $0.3 \%$ ).

In the black shales the content of $\mathrm{CaO}$ is $2.1 \%$. Probably $\mathrm{Ca}$ is bound into carbonates, as is half of the total (3\%) MgO. The calculated calcite and dolomite content in black shales is $7.5 \%$ on average. The clarkes of $\mathrm{Mn}$ and $\mathrm{Sr}$ in shales of the East European Platform are 600 and 140 ppm, respectively, and that of $\mathrm{CaO}$ $8.9 \%$ (Gromet et al., 1984).

\section{Redox-sensitive elements}

This group includes the metals, most of which have a changing valency: $\mathrm{Cr}$, $\mathrm{Ni}, \mathrm{V}, \mathrm{Zn}, \mathrm{Mn}, \mathrm{Fe}, \mathrm{Pb}, \mathrm{Mo}, \mathrm{U}$, and non-metals $\mathrm{S}$ and As. Mn as an element associated with carbonates was discussed in the previous section.

\section{Organic matter and sulphur}

In general, the elements $\mathrm{Cr}, \mathrm{Ni}, \mathrm{V}, \mathrm{Zn}, \mathrm{Pb}, \mathrm{As}, \mathrm{Mo}, \mathrm{U}, \mathrm{Fe}$, and $\mathrm{S}$ associate with organic matter and their average contents are increased in black shales as compared to the shales without organic matter. LOI, used as a substitute for organic matter analysis, has values between 7.9 and $25.5 \%$, on average $15.6 \%$. In some samples the maximum contents of several elements do not coincide with maximums of LOI, but are shifted. $\mathrm{Zn}, \mathrm{Pb}$, $\mathrm{As}$, and Mo have only clarke values in some samples although the content of organic matter is on the average level. $\mathrm{Ni}, \mathrm{Cr}$, and V correlate best with LOI $(0.85,0.75$, and 0.79 , respectively). The correlation coefficient between $\mathrm{S}$ and LOI is 0.49 . The $\mathrm{S}$ content is between 0.5 and $3.2 \%$, on average $1.2 \%$.

$\mathrm{Fe}, \mathrm{Pb}$, and As show good correlation with sulphur $(0.69,0.84$, and 0.69 , respectively). Previously $S$ was considered to be bound in pyrite with a necessary amount of $\mathrm{Fe}$. Because there is good correlation between $\mathrm{Pb}$, As, and S, the first two must also be connected with pyrite. Vaughan \& Craig (1981, p. 419) give the approximate contents of $\mathrm{Pb} 0.5 \%$ and $\mathrm{As} 5 \%$ in pyrite. $\mathrm{V}$ has no affinity for pyrite either in Aizpute black shales or in the Tremadoc Dictyonema Shale in North Estonia (Loog, 1982). The formation of galenite as a selfdependent $\mathrm{Pb}$ mineral is also possible. The $\mathrm{Pb}$ content in black shale is between 16 and $356 \mathrm{ppm}$, median $42 \mathrm{ppm}$, the As content is between 8 and $325 \mathrm{ppm}$, median $20 \mathrm{ppm}$.

\section{Reactive iron}

$\mathrm{Fe}$ in excess of the terrigenous silicate contribution is treated here as reactive iron. In black shales reactive Fe is bound in pyrite. Its calculated content depends on the preciseness of $\mathrm{S}$ analysis. The total Fe content in black shale samples is from 4.6 to $8.1 \%$, that of reactive $\mathrm{Fe}$ is between 0.7 and $4.0 \%$. The total $\mathrm{Fe}$ content is anomalously high on three levels: A975.8 - 8.1\%, A974.75 - 7.2\%, 
and A973.8 - 7.6\%. These levels, and additionally also A969.8, show higher pyrite values as well (calculated according to the $\mathrm{S}$ content).

\section{Zinc}

$\mathrm{Zn}$ is relatively independent from the other redox-sensitive elements with which it has a positive but weak correlation: correlation coefficients of 0.41-0.49 with LOI, $\mathrm{Ni}, \mathrm{Cr}$, and $\mathrm{V}$. The highest correlation coefficient of 0.67 is recorded between $\mathrm{Zn}$ and Mo. A good correlation between $\mathrm{Zn}$ and Mo is due to the coinciding anomalies of these elements in spite of the shift of the peak maxima. The $\mathrm{Zn}$ concentration is anomalously high in four samples, from 1190 to $2360 \mathrm{ppm}$, in the other samples it falls to the level of clarke, to $60-80 \mathrm{ppm}$. The median of the $\mathrm{Zn}$ content is $315 \mathrm{ppm}$. Supposedly $\mathrm{Zn}$ forms sphalerite crystals, occurring randomly in samples.

\section{Molybdenum and uranium}

Contrary to $\mathrm{Zn}$, which shows anomalously high but sharp peaks, the increasing Mo values join into broad peaks which connect some successive samples. Every such Mo anomaly correlates with an increase in some other element. Mo is in good correlation with $\mathrm{V}, \mathrm{Ni}$, and $\mathrm{Cr}(0.73,0.65$, and 0.59 , respectively) which have coincident increase levels, sometimes with shifted peak maxima (the levels of 976.3-974.75 m, 974.0-973.8 m, 971.5-971.25 m, and $969.45 \mathrm{~m})$. Meanwhile the content of Mo falls down to the clarke level. The correlation of Mo with LOI is good (coefficient 0.55 ), but modest with S (coefficient 0.34). The Mo content is between 0 and $270 \mathrm{ppm}$, on average $45 \mathrm{ppm}$.

$\mathrm{U}$ exceeds the detection limit (10 ppm) in three samples, amounting to $25-70$ $\mathrm{ppm}$. With the anomalies of other elements U coincides only in sample A969.45, having there the maximum content of $70 \mathrm{ppm}$.

\section{Chromium, vanadium, and nickel}

$\mathrm{Cr}, \mathrm{V}$, and $\mathrm{Ni}$ have the best correlation with each other (correlation coefficient 0.9). The $\mathrm{Cr}$ content is between 90 and $236 \mathrm{ppm}$, on average $120 \mathrm{ppm}$. The $\mathrm{V}$ content is between 180 and $1800 \mathrm{ppm}$, on average $570 \mathrm{ppm}$. The Ni content is between 100 and $240 \mathrm{ppm}$, on average $130 \mathrm{ppm}$. The average contents of these elements in excess of the terrigenous contribution for the interval of 969.15 to $975.4 \mathrm{~m}$ (except the limestone interval of $974.0-974.7 \mathrm{~m}$ ) are as follows: Cr 47 ppm, V 489 ppm, and Ni 92 ppm for black shale samples. Their ratio $1: 10: 1.9$ is in good agreement with the respective $\mathrm{Cr} / \mathrm{V} / \mathrm{Ni}$ ratio $1: 10: 2$ in recent oceans (contents in seawater according to Piper \& Isaacs, 1995): $\left.\mathrm{CrO}_{4}{ }^{2-}-4.04 \cdot 10^{-9}, \mathrm{H}_{2} \mathrm{VO}_{4}{ }^{-}-4 \cdot 10^{-8}, \mathrm{Ni}^{2+}-8.01 \cdot 10^{-9} \mathrm{~mol} / \mathrm{kg}\right)$. The $\mathrm{Cr} / \mathrm{V} \cdot 0.1$ ratio is between 0.5 and 1.9 (on average 1.0 ), the $\mathrm{Ni} / \mathrm{V} \cdot 0.1$ ratio is between 1.0 and 4.2 (on average 2.45 ). The similarity of the proportions in rock to those in seawater shows accumulation directly from the seawater - from the hydrogenous source - involving equilibrium thermodynamics. In the lower part of the black shale profile (below $975.4 \mathrm{~m}$ ) the ratio is out of this regularity. The values in 
excess of terrigenous contribution are: low for $\mathrm{V}$ - from 60 to $130 \mathrm{ppm}$, relatively high for $\mathrm{Ni}-130 \mathrm{ppm}$, and modest for $\mathrm{Cr}-35 \mathrm{ppm}$.

\section{Vertical distribution of chemical elements}

The contents of $\mathrm{Cr}, \mathrm{V}$, and $\mathrm{Ni}$ are constantly high through the black shale. The other metals tend to concentrate on certain levels. In the investigated section there are five levels where the contents of the majority of the elements analysed exceed the average background of black shale, and a limestone interbed where all metal contents are low. The first level of elevated concentrations is in the interval of samples A976.3 to A975.4, showing an increase in $\mathrm{S}, \mathrm{Fe}_{2} \mathrm{O}_{3}, \mathrm{~Pb}, \mathrm{As}$, $\mathrm{Ni}, \mathrm{Mo}$, and $\mathrm{Zn}$. The anomalies in $\mathrm{A} 975.8$ probably associate with pyrite.

The next level is in the lower interface of black shale and 0.7-m-thick limestone interval, $974.75 \mathrm{~m}$. It is mainly characterized by an increase in pyrite and associated elements $\mathrm{Pb}$ and $\mathrm{As}$.

The third level is above the upper limestone-black shale interface. Immediately on the contact with limestone, in sample A974.0, there is an anomaly of $\mathrm{Ni}, \mathrm{Cr}$, and $\mathrm{V}$. The LOI value is high, $25 \%$. Increased contents of $\mathrm{Zn}$, $\mathrm{Mo}, \mathrm{Pb}$, As, $\mathrm{Fe}$, and $\mathrm{S}$ occur $20 \mathrm{~cm}$ higher, in $\mathrm{A} 973.8$.

Upwards, on the fourth level, the anomaly of Mo and $\mathrm{Zn}$ in association with increased LOI is observed in A971.5 and A971.25. These samples represent an interval of visually homogeneous black shale from 974.0 to $970.55 \mathrm{~m}$.

The oscillations in redox-sensitive elements begin with the alternation of black and grey shales in the upper part of the section. The transitional zone is represented by several samples, of which one, A969.45, shows particularly high contents of most of the redox-sensitive elements: Mo 270 ppm, Ni $240 \mathrm{ppm}, \mathrm{Cr}$ 240 ppm, V 1800 ppm, Zn 2360 ppm, U 70 ppm, and LOI 25\%. The peak of S (pyrite anomaly) does not occur in this sample. Higher contents of pyriteassociated elements are in A969.8 - $\mathrm{Pb} 220 \mathrm{ppm}$ and As $325 \mathrm{ppm}$. This sample has a higher content of $\mathrm{CaO}(13.7 \%)$ and carbonate-associated elements $\mathrm{Mn}$ $(1230 \mathrm{ppm})$ and $\mathrm{Sr}(230 \mathrm{ppm})$.

A certain tendency is observed in the distribution of $\mathrm{Ca}$. In the lower 3-m part of the sequence up to the 0.7 -m-thick limestone interbed the content of $\mathrm{CaO}$ is quite stable and low (1.5\%). Above the limestone interbed a gradual increase in $\mathrm{CaO}$ from 1.4 (A973.8) to 8.2\% (A970.7) takes place, up to the end of the homogeneous black shale. The highest $\mathrm{CaO}$ content in black shale is $13.5 \%$ in A969.8. On the level of $969.55-969.65 \mathrm{~m}$ there is a limestone nodule - fine to microcrystalline with rare recrystallized fossils. Upward rare thin $(10 \mathrm{~cm})$ fossiliferous limestone interbeds occur in grey shale.

$\mathrm{Si}$ is the basic constituent of quartz, clay minerals, and K-feldspar. The $\mathrm{Si} / \mathrm{Al}$ ratio reflects mainly the quartz+K-feldspar/clay mineral ratio. As quartz is more abundant in the coarse fraction than in the fine fraction, the $\mathrm{SiO}_{2} / \mathrm{Al}_{2} \mathrm{O}_{3}$ ratio probably reflects also grain size relations of terrigenous material. This presumption is based on X-ray diffraction measurements of quartz intensities in 
the terrigenous component of several black shale and limestone samples. The terrigenous composition of these samples is similar, with little variation in peak intensities, thus confirming the small variations in the $\mathrm{SiO}_{2} / \mathrm{Al}_{2} \mathrm{O}_{3}$ ratio between these samples. Figure 4 shows $\mathrm{X}$-ray diffractograms of the terrigenous fraction of limestone sample A974.05. In diffractograms quartz, K-feldspar, plagioclase, illite, chlorite, and kaolinite are represented. The $\mathrm{Al}_{2} \mathrm{O}_{3} / \mathrm{SiO}_{2}$ ratio as well has been used as a granulometric indicator for Tremadoc Dictyonema Shale (Pukkonen \& Rammo, 1992).

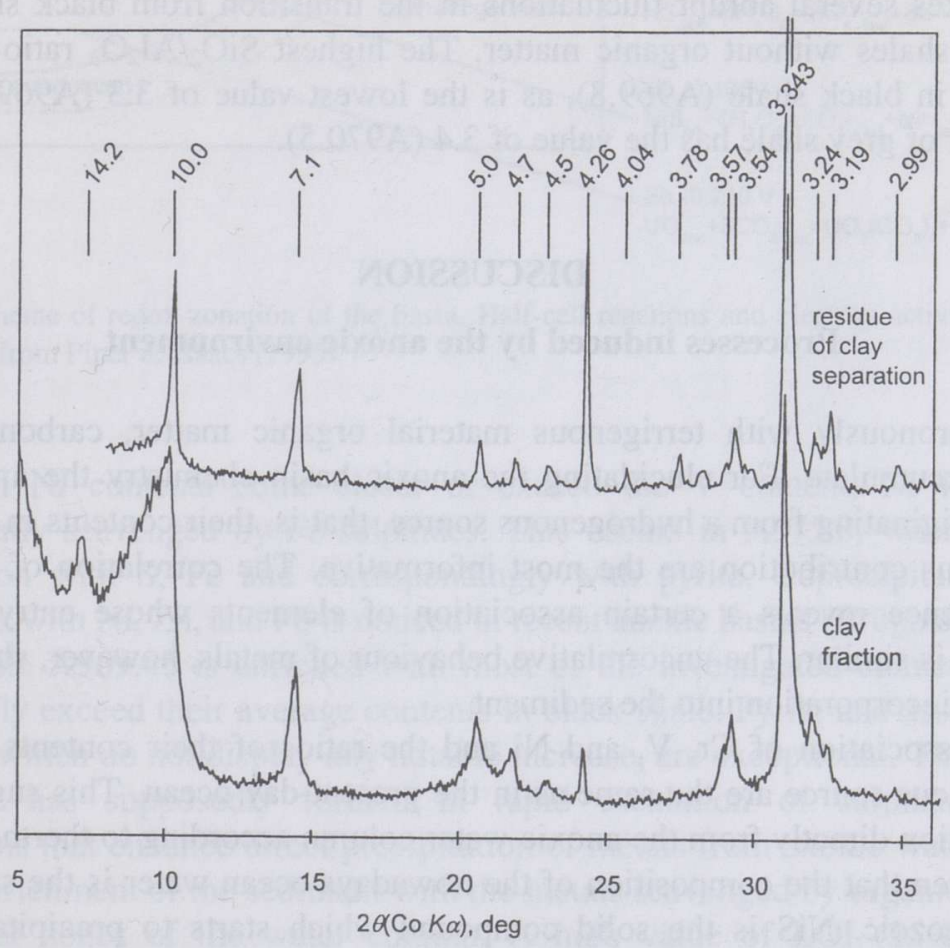

Fig. 4. X-ray diffractograms of the terrigenous component from limestone sample A974.05 (carbonate minerals removed by $0.5 \mathrm{~N} \mathrm{HCl}$ ). The $d$-spacings in $\AA$ are given at the top. The following minerals were identified: illite (reflections at 10.0, 5.0, and 4.5 $\AA$ ); chlorite (14.2, 7.1, 4.7, and $3.54 \AA$ ); quartz (4.26 and $3.343 \AA$ ); K-feldspar (3.78, 3.24, and $2.99 \AA$ ); plagioclase (4.04 and $3.19 \AA)$; kaolinite $(3.57 \AA)$.

The $\mathrm{SiO}_{2} / \mathrm{Al}_{2} \mathrm{O}_{3}$ ratio (Fig. 3) shows a trend towards an increase simultaneously with the growth of the $\mathrm{CaO}$ content in the interval of 974.0 to $969.15 \mathrm{~m}$ (correlation coefficient 0.75 ). The $\mathrm{SiO}_{2} / \mathrm{Al}_{2} \mathrm{O}_{3}$ ratio is duplicated by the $\mathrm{Zr} / \mathrm{Al}_{2} \mathrm{O}_{3}$ ratio. Both ratios are correlative in the sequence, except for the $0.7-\mathrm{m}$ limestone interbed. $\mathrm{Zr}$ is supposed to originate from terrigenous zircon (Jürgenson, 1988) and, similar to quartz, be indicative of a coarse fraction. If 
quartz had been of authigenic origin, the increase in Si would not have been accompanied by an increase in $\mathrm{Zr}$.

The limestone interbed from 974.05 to $974.7 \mathrm{~m}$ has extremely high $\mathrm{Zr} / \mathrm{Al}_{2} \mathrm{O}_{3}$ values compared to black shales. The $\mathrm{SiO}_{2} / \mathrm{Al}_{2} \mathrm{O}_{3}$ ratio decreases to 2.1 in a coarse-crystalline layer (A974.6). In adjacent limestone it has an average value of 3.7. After treating the rock from this coarse-crystalline interlayer with acetic acid an unusual residue is left: it does not contain quartz, but silicates of probably authigenic origin.

In the upper part of the sequence (from A970.5 to A969.15) the $\mathrm{SiO}_{2} / \mathrm{Al}_{2} \mathrm{O}_{3}$ ratio makes several abrupt fluctuations in the transition from black shales into adjacent shales without organic matter. The highest $\mathrm{SiO}_{2} / \mathrm{Al}_{2} \mathrm{O}_{3}$ ratio of 4.1 is recorded in black shale (A969.8), as is the lowest value of 3.3 (A969.15). The interlayer of grey shale has the value of 3.4 (A970.5).

\section{DISCUSSION}

\section{Processes induced by the anoxic environment}

Synchronously with terrigenous material organic matter, carbonates, and metals accumulate. For elucidating the anoxic basin chemistry the amounts of metals originating from a hydrogenous source, that is, their contents in excess of terrigenous contribution are the most informative. The correlation of metals in the sequence reveals a certain association of elements whose entry into the sediment is similar. The uncorrelative behaviour of metals, however, shows their different incorporation into the sediment.

The association of $\mathrm{Cr}, \mathrm{V}$, and $\mathrm{Ni}$ and the ratios of their contents from the hydrogenous source are the same as in the present-day ocean. This suggests the precipitation directly from the anoxic water column according to thermodynamic rules, given that the composition of the nowadays ocean water is the same as in the Palaeozoic. NiS is the solid compound which starts to precipitate at the lowest Eh $(-0.188 \mathrm{~V})$ compared to $\mathrm{V}$ and $\mathrm{Cr}$ (Piper \& Isaacs, 1995). So, the redox potential of the anoxic zone of the basin ought to be lower than $-0.188 \mathrm{~V}$, which indicates a strongly sulphate-reducing environment. The distribution of $\mathrm{V}$ in several basins suggests its reduction under sulphate-reducing conditions only (Emerson \& Huested, 1991, cited in Piper \& Isaacs, 1995). The scheme of the basin stratification, based on the Eh data from Piper \& Isaacs (1995), is presented in Fig. 5.

The anoxic sulphate-reducing bottom water was possibly overlain by a rather thin denitrifying zone. Widening of this zone is probable in the cases when the ratio between the $\mathrm{Cr}$ and $\mathrm{Ni}$ accumulated from a hydrogenous source exceeds $1: 2$, while $\mathrm{V} / \mathrm{Ni}$ stays near $10: 1$. This occurs in sample A974.0 since $\mathrm{Cr}$ reduction and precipitation begins in the denitrifying environment (Piper \& Isaacs, 1995). 


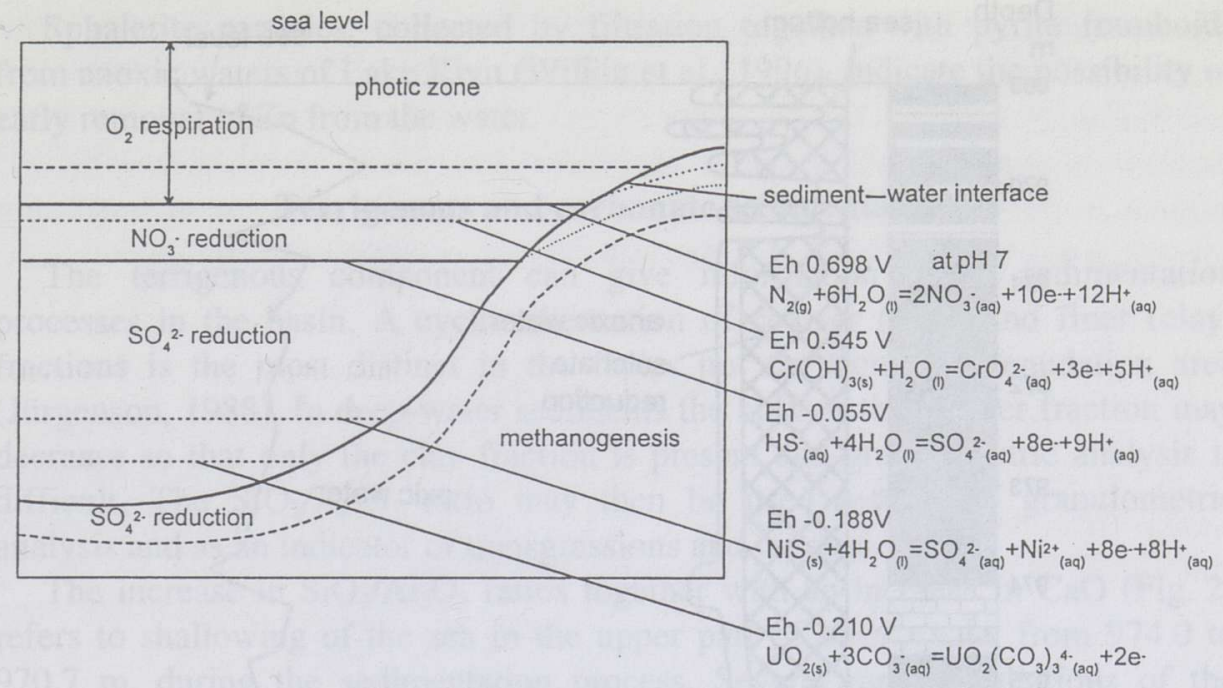

Fig. 5. Scheme of redox zonation of the basin. Half-cell reactions and electron activity (Eh) data (at $\mathrm{pH}$ 7) from Piper \& Isaacs (1995).

When $\mathrm{Ni}$ contents come closer or exceed the $\mathrm{V}$ content, $\mathrm{Ni}$ is possibly additionally scavenged by $\mathrm{Fe}$ sulphides. This occurs in A975.8, where $\mathrm{Ni}$ is in correlation with $\mathrm{S}, \mathrm{Fe}$ and correspondingly with pyrite. Coprecipitating of $\mathrm{Fe}$ sulphides with $\mathrm{Ni}, \mathrm{Zn}$, and $\mathrm{Pb}$ is noticed in recent anoxic basins (Brügmann, 1988).

Sample A969.45 is enriched with most of the investigated elements, which repeatedly exceed their average contents in black shale. Pyrite and associated $\mathrm{Pb}$ and As, which do not display any notable increase, are exceptional. The A969.45 anomaly has supposedly formed in rapid escalation of sulphate-reducing conditions that enhance direct precipitation of metals from anoxic water, as well as the enrichment of the sediment with the metals scavenged by organic matter in the upper zones of the water column. A high value of LOI $(25 \%)$ and the presence of uranium indicate a stronger reducing environment in the bottom water. The anomaly cannot be treated as a decrease in "diluting" terrigenous input as the metal/LOI ratios are too high as compared to the average of Aizpute black shale.

Sample A969.15 from a thin black shale interbed adjacent to grey shale is also characterized by an increased content of metals. This may be treated as an example of the enrichment with metals in the periphery of the stagnant zone (Manheim, 1961). Replenishing of seawater with metals during frequent basin flushing, probably at the end of the Aeronian, may as well have caused the increased metal accumulation in the sediment on certain levels.

Figure 6 shows the schematic development of redox conditions in the basin according to the data from the Aizpute section. 


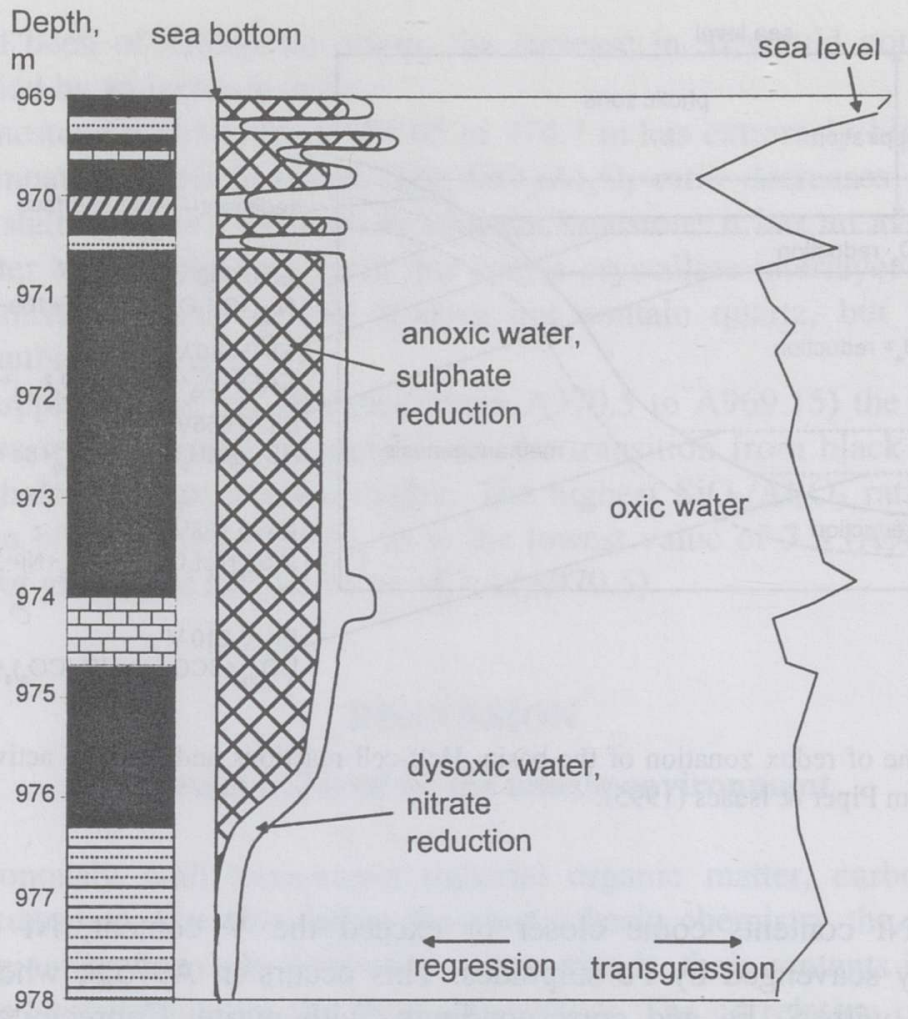

Fig. 6. Schematic sea-level fluctuations and redox stratification of seawater in the Middle Llandovery at Aizpute. Sea-level curve based on the $\mathrm{SiO}_{2} / \mathrm{Al}_{2} \mathrm{O}_{3}$ ratio, with some modifications explained in text. For legend see Fig. 2.

Pyrite is an important authigenic compound in black shale. It is finedispersed, with the background content of $2 \%$. It forms in the interface of oxic and anoxic environments in the water column or in fresh sediment (Wilkin et al., 1996). The anomaly in the interface of two lithologic varieties on the A974.75 level can be treated on analogy with the Tremadoc Dictyonema Shale as late diagenetic pyrite, formed by lithification of sediment (Kallaste \& Pukkonen, 1992). The reasons for the formation of pyrite anomalies in A975.8, A973.8, and A969.8 remain uncertain.

In pyrite the Mo addition may be $30 \mathrm{ppm}$, in sphalerite $100 \mathrm{ppm}$ (Vaughan \& Craig, 1981). In the Tremadoc Dictyonema Shale the Mo content in pyrite concretions is from 5.6 to $150 \mathrm{ppm}$, which is 7.5 times higher than in host rock (Loog, 1982). According to recent investigations, Mo removal is connected with oxythiomolybdate scavenging by $\mathrm{Fe}$ and the presence of organic particles in the sulphidic water column. Reaching the sediment, Mo forms two minerals: a $\mathrm{Fe}-\mathrm{Mo}$ sulphide, and Mo-O-S bound with organic matter (Helz et al.,1996). 
Sphalerite particles, collected by filtration together with pyrite framboids from anoxic waters of Lake Kivu (Wilkin et al., 1996), indicate the possibility of early removal of $\mathrm{Zn}$ from the water.

\section{Terrigenous and carbonate sedimentation}

The terrigenous component can give information about sedimentation processes in the basin. A cyclic alternation of coarser (silty) and finer (clay) fractions is the most distinct in the facies not far from the denudation area (Jürgenson, 1988). In deep-water sediments the bulk of the coarser fraction may decrease so that only the clay fraction is present and granulometric analysis is difficult. The $\mathrm{SiO}_{2} / \mathrm{Al}_{2} \mathrm{O}_{3}$ ratio may then be used instead of granulometric analysis and as an indicator of transgressions and regressions.

The increase in $\mathrm{SiO}_{2} / \mathrm{Al}_{2} \mathrm{O}_{3}$ ratios together with an increase in $\mathrm{CaO}$ (Fig. 2) refers to shallowing of the sea in the upper part of black shale, from 974.0 to $970.7 \mathrm{~m}$, during the sedimentation process. Several rapid oscillations of the $\mathrm{SiO}_{2} / \mathrm{Al}_{2} \mathrm{O}_{3}$ ratio follow in the interval from 970.5 to $969.45 \mathrm{~m}$ characterized by the alternation of black shales, grey shales, and calcite-rich interlayers. Judging from decreasing $\mathrm{SiO}_{2} / \mathrm{Al}_{2} \mathrm{O}_{3}$ values, upwards from the level of $969.4 \mathrm{~m}$ deeperwater sedimentation is re-established. In the Aizpute region the deep-water sedimentation continues in the Telychian though the sulphate-reducing environment has disappeared. The connection of spreading of the black, organicrich shale facies with eustasy, expressed as $\mathrm{Si}$ and $\mathrm{Zr}$ ratios to $\mathrm{Al}$, shows no direct relation between the transgression and widening of the anoxic facies in the shelf. The low $\mathrm{SiO}_{2} / \mathrm{Al}_{2} \mathrm{O}_{3}$ ratio of 3.3-3.4, indicative of the transgressive period, may be characteristic of a black shale sample (A969.15) as well as of shale without organic matter (A970.5). A higher value of 4.1 in A969.8, referring to the regression, is recorded also in black shale.

Figure 6 reveals two modifications of the $\mathrm{SiO}_{2} / \mathrm{Al}_{2} \mathrm{O}_{3}$ ratio used as a base for drawing the sea-level curve (cf. Fig. 2). One is on the level of $974.6 \mathrm{~m}$, where anomalous in mineralogical composition (in the terrigenous fraction the absence of quartz, presence of authigenic (?) K-feldspar) coarse-crystalline limestone occurs. The other modification is connected with the level of $975.8 \mathrm{~m}$, where the $\mathrm{CaO}$ content does not increase simultaneously with $\mathrm{SiO}_{2} / \mathrm{Al}_{2} \mathrm{O}_{3}$ and $\mathrm{Zr} / \mathrm{Al}_{2} \mathrm{O}_{3}$ ratios. The explanation for the rise of the $\mathrm{SiO}_{2} / \mathrm{Al}_{2} \mathrm{O}_{3}$ ratio may be an increase in the input of coarser terrigenous material due to rearrangements in the denudation area, and not regression.

The interbedding of limestone and black shales is observed in Aeronian rocks in West Latvia.

It is not clear whether the $0.7-\mathrm{m}$-thick limestone interbed, and $\mathrm{CaO}$ enrichment caused by an increase in the carbonate mineral content inside black shale, which is the most distinct in sample A969.8, are the products of the same chemical process. The terrigenous matter from the 0.7 -m-thick limestone interbed, except the coarse-crystalline interlayer (see above), has the 
mineralogical composition and proportions between terrigenous minerals similar to those of black shale. This means that geochemical conditions in the seawater and distance from the denudation area remained unchanged. Otherwise, a slight increase in the $\mathrm{SiO}_{2} / \mathrm{Al}_{2} \mathrm{O}_{3}$ ratio corresponding to the $\mathrm{CaO}$ increase, which is highest in $\mathrm{A} 969.8\left(\mathrm{SiO}_{2} / \mathrm{Al}_{2} \mathrm{O}_{3}\right.$ ratio $4.1, \mathrm{CaO}$ content $\left.13.7 \%\right)$, indicates the favouring effect of onshore conditions on the sedimentation of carbonates.

\section{CONCLUSIONS}

In the Aizpute- 41 core the contents of metals are enhanced as compared to the shales without organic matter. $\mathrm{Cr}, \mathrm{V}$, and $\mathrm{Ni}$ have elevated background values throughout the sequence, with synchronous anomalies on some levels. Supposing the stable composition of the seawater through geological time, we may conclude that the $\mathrm{Cr}, \mathrm{V}$, and $\mathrm{Ni}$ contents in Aizpute black shales reflect the conditions during sedimentation in the basin. The ratios of their hydrogenous components, on average $1: 10: 1.9$ in the upper half of the Aizpute black shale sequence and $1: 10: 2$ in recent marine water, hint at the precipitation from the anoxic water column with Eh equal to or lower than Eh available for Ni sulphide precipitation. This gives evidence of a sulphate-reducing environment in the bottom water of the basin, probably overlain by a rather thin denitrification zone. In the lower part of the black shale from 976.3 to $975.4 \mathrm{~m}$ the ratio is out of this regularity, mainly due to too low $\mathrm{V}$ contents. That interval supposedly corresponds to the period of the beginning invasion of the anoxic conditions.

$\mathrm{S}, \mathrm{Mo}, \mathrm{Zn}$, and $\mathrm{U}$ add to the information about the environment. They support the conclusion about sulphate-reducing conditions in the sediment and nearbottom basin water.

The Fe enrichment mechanism on the levels of an increased pyrite content is uncertain. Probably there occurred diagenetic enrichment with pyrite in the black shale-limestone interface. Pyrite correlates with $\mathrm{Pb}$, As, and in some samples additionally with $\mathrm{Mo}, \mathrm{Ni}$, and $\mathrm{Zn}$. The association of these elements and pyrite reveals a similar mechanism of enrichment, maybe scavenging of the elements by iron sulphides in the water column.

Supposedly, carbonates in black shale have precipitated chemogenically in the deep-water anoxic environment. This could account for the formation of a 0.7-m-thick limestone interbed. Positive correlation of the $\mathrm{CaO}$ content and $\mathrm{SiO}_{2} / \mathrm{Al}_{2} \mathrm{O}_{3}$ ratio in the upper half of the black shales, however, reveals an increase in carbonate sedimentation when the shallower nearshore zone shifted towards the Aizpute area. The genesis of limestone interbedding in black shales needs further investigation.

The $\mathrm{SiO}_{2} / \mathrm{Al}_{2} \mathrm{O}_{3}$ ratio is duplicated by the $\mathrm{Zr} / \mathrm{Al}_{2} \mathrm{O}_{3}$ ratio, thus supporting the supposition about the terrigenous origin of silica. The $\mathrm{SiO}_{2} / \mathrm{Al}_{2} \mathrm{O}_{3}$ ratio is used as a substitute for granulometric analysis and as an index of transgressions and 
regressions. The $\mathrm{SiO}_{2} / \mathrm{Al}_{2} \mathrm{O}_{3}$ ratio shows no direct connection between the expansion or disappearance of the anoxic marine environment and transgressions-regressions of the seawater in the Aizpute region in the Aeronian. The black shale facies tends to behave independently from eustasy.

\section{ACKNOWLEDGEMENTS}

The research was supported by grant No. 2651 of the Estonian Science Foundation. The author thanks Erika Jürgenson for the lithological description of the Aizpute core, Toivo Kallaste for X-ray diffraction measurings and help in field work, and Tarmo Kiipli, initiator of this investigation, for help in field work and useful advise.

\section{REFERENCES}

Aisatullin, T. A. \& Skopintsev, B. A. 1979. Specifics of the chemistry of the basins with anaerobic zones. In Okeanologiya. Chimiya okeana, 1. Chimiya vod okeana (Monin, A. S., ed.). Nauka, Moscow, 288-324 (in Russian).

Bassett, M. G, Kaljo, D. \& Teller, L. 1989. The Baltic region. In A Global Standard for the Silurian System (Holland, C. H. \& Bassett, M. G., eds.). Geological Series, 9. National Museum of Wales, Cardiff, 158-170.

Berner, R. A. 1970. Sedimentary pyrite formation. Amer. J. Sci., 268, 1-23.

Berry, W. B. N., Wilde, P. \& Quinby-Hunt, M. S. 1989. Palaeozoic (Cambrian through Devonian) anoxitropic biotopes. Palaeo. Palaeo. Palaeo., 74, 3-13.

Brügmann, L. 1988. Some peculiarities of the trace-metal distribution in Baltic waters and sediments. Mar. Chem., 23, 425-440.

Brügmann, L., Hallberg, R., Larsson, C. \& Löffler, A. 1997. Changing redox conditions in the Baltic Sea Deep basins: Impacts on the concentration and speciation of trace metals. Ambio, 26, 2, 107-112.

Gromet, L. P., Dymek, R., Haskin, L. A. \& Korotev, R. 1984. The North American Shale composite: Its compilation, major and trace element characteristics. Geochim. Cosmochim. Acta, 48, 2469-2482.

Helz, G. R., Miller, C., Charnock, J., Mosselmans, J., Pattrick, R., Garner, C. \& Vaughan, D. 1996. Mechanism of molybdenum removal from the sea and its concentration in black shales: EXAFS evidence. Geochim. Cosmochim. Acta, 60, 3631-3642.

Jürgenson, E. 1988. Deposition of the Silurian Beds in the Baltic. Valgus, Tallinn (in Russian).

Kaljo, D. \& Jürgenson, E. 1977. Sedimentary facies of the East Baltic Silurian. In Facies and Fauna of the Baltic Silurian (Kaljo, D., ed.). Tallinn, 122-148 (in Russian).

Kallaste, T. \& Pukkonen, E. 1992. Pyrite varieties in Estonian Tremadocian argillite (Dictyonema Shale). Proc. Estonian Acad. Sci. Geol., 41, 1, 11-22.

Lepland, A. \& Stevens, R. L. 1996. Authigenic manganese mineralogy in the Landsort Deep, westcentral Baltic Sea. Geol. Fören. Stockh. Förh., 118, 118-119. 
Loog, A. 1982. On the chemistry of postsedimentary mineral formation in the graptolitic argillites of North-Estonian Tremadoc. In Lithostratigraphy and Mineralogy of Bedrocks. Acta et Comment. Univ. Tartuensis, 527, 44-49 (in Russian).

Manheim, F. T. 1961. A geochemical profile in the Baltic Sea. Geochim. Cosmochim. Acta, 25, $52-70$.

Nestor, H. \& Einasto, R. 1982. Application of shelf and slope concepts to the Silurian Baltic Basin. In Ecostratigraphy of the East Baltic Silurian (Kaljo, D. \& Klaamann, E., eds). Valgus, Tallinn, 17-24.

Nestor, V. 1994. Early Silurian Chitinozoans of Estonia and Latvia. Academia, 4. Estonian Academy Publishers, Tallinn.

Piper, D. Z. \& Isaacs, C. M. 1995. Geochemistry of Minor Elements in the Monterey Formation, California: Seawater Chemistry of Deposition. U. S. Geological Survey Professional Paper, 1566. Washington.

Pukkonen, E. \& Rammo, M. 1992. Distribution of molybdenum and uranium in the Tremadoc graptolitic argillite (Dictyonema shale) of North-Western Estonia. Bulletin of the Geological Survey of Estonia, 2/1, 3-15.

Salonen, V., Grönlund, T., Itkonen, A., Sturm, M. \& Vuorinen, I. 1995. Geochemical record on early diagenesis of recent Baltic Sea sediments. Mar. Geol., 129, 101-109.

Vaughan, D. \& Craig, J. 1981. Mineral Chemistry of Metal Sulfides. Mir, Moscow (in Russian).

Voitkevich, G. V., Miroshnikov, A. E., Povarennykh, A. S. \& Prokhorov, V. G. 1977. Kratkij spravochnik po geokhimii. Nedra, Moscow (in Russian).

Wilkin, R. T., Barnes, H. L. \& Brantley, S. L. 1996. The size distribution of framboidal pyrite in modern sediments: An indicator of redox conditions. Geochim. Cosmochim. Acta, 60, 3897-3912.

\title{
AIZPUTE-41 PUURAUGU (LÄÄNE-LÄTI) LLANDOVERY MUSTA KILDA GEOKEEMIA
}

\author{
Enli KIIPLI
}

Aizpute puuraugu Kesk-Llandovery vanusega musta kilda 7,2 m paksuses läbilõikes on röntgenfluorestsentsmeetodil analüüsitud mikro- ja makrokomponentide sisaldust. $\mathrm{Cr}, \mathrm{V}$ ja $\mathrm{Ni}$ hüdrogeensest allikast pärit keskmise sisalduse suhtvahekord on läbilõike kesk- ja ülaosas ligikaudu $1: 10: 1,9$. See viitab nende elementide väljasadenemisele mereveest sulfaatredutseerivas keskkonnas, kus Eh on niisama suur või madalam kui NiS-i väljasadenemise Eh. Püriidiga assotsieeruvad elemendid $\mathrm{Pb}$, As, mõnel juhul ka $\mathrm{Zn}$, Ni ja Mo ei ole pideva ühtlase kõrgenenud sisaldusega, vaid koonduvad kindlatele tasanditele. Nende settesse kinnistumise mehhanism ei ole üheselt määratud.

$\mathrm{SiO}_{2} / \mathrm{Al}_{2} \mathrm{O}_{3}$ suhet on käsitletud kui jäme- ja peenpurru suhte indikaatorit, mis viitab basseini veetaseme transgressiivsetele ja regressiivsetele liikumistele. $\mathrm{SiO}_{2} / \mathrm{Al}_{2} \mathrm{O}_{3}$ positiivne korrelatsioon $\mathrm{CaO}$ sisaldusega läbilõikes lubjakivi vahekihist kõrgemal näitab karbonaatsete mineraalide soodsamaid tekketingimusi musta kilda faatsiese rannalähedasemas piirkonnas. Lubjakivi $0,7 \mathrm{~m}$ paksuses vahekihis ei ole mainitud korrelatiivset sõltuvust. See lubab oletada lubjakivi 
keemilist väljasadenemist süvaveelises sulfaatredutseerivas keskkonnas, kusjuures $\mathrm{SiO}_{2} / \mathrm{Al}_{2} \mathrm{O}_{3}$ suhe ei viita regressioonile. Musta kilda faatsiese ilmumine või kadumine ei peegeldu $\mathrm{SiO}_{2} / \mathrm{Al}_{2} \mathrm{O}_{3}$ suhte muutuses, s.t. hapnikuvaene keskkond meres areneb transgressioonist ja regressioonist suhteliselt sõltumatult.

\section{ГЕОХИМИЯ ЛЛАНДОВЕРИЙСКИХ ЧЕРНЫХ СЛАНЦЕВ В РАЗРЕЗЕ СКВАЖИНЫ АЙЗПУТЕ-41, ЗАПАДНАЯ ЛАТВИЯ}

\section{Энли КИЙПли}

Рентгенофлюоресцентным методом изучено содержание микро- и макрокомпонентов в черных сланцах среднелландоверийского возраста, мощность которых в разрезе скв. Айзпуте составляет 7,2 м. В верхней и средней частях разреза среднее содержание гидрогенных компонентов $\mathrm{Cr}$, V и Ni находится в соотношении $1: 10: 1,9$, что указывает на выпадение этих элементов из сульфатредуцирующей среды, где Eh ниже или соответствует Eh, при которой начинается выпадение NiS. Повышенная концентрация ассоциирующих с пиритом $\mathrm{Pb}$, As, а иногда $\mathrm{Zn}$, Ni и $\mathrm{Mo}$ отмечена лишь на определенных уровнях. Связующий их в осадок механизм однозначно не определен.

Соотношение $\mathrm{SiO}_{2} / \mathrm{Al}_{2} \mathrm{O}_{3}$, принятое за индикатор соотношения крупнои мелкообломочного материала, указывает на трансгрессивные и регрессивные движения морской воды. Позитивная корреляция между $\mathrm{SiO}_{2} / \mathrm{Al}_{2} \mathrm{O}_{3}$ и содержанием $\mathrm{CaO}$, а также рост этих показателей в разрезе выше прослоя известняка говорят о том, что формированию карбонатных минералов черносланцевой фации благоприятствовало смещение седиментационной зоны в сторону мелководья в результате регрессии. Однако упомянутая зависимость не распространяется на 0,7-метровую толщу известняка в черных сланцах. Следовательно, эта толща могла сформироваться чисто химически - в сульфатредуцирующей среде.

Возникновение или исчезновение черносланцевой фации не отражается на соотношении $\mathrm{SiO}_{2} / \mathrm{Al}_{2} \mathrm{O}_{3}$, т. е. бедная кислородом морская среда развивалась вне зависимости от трансгрессивных и регрессивных движений. 